\title{
Primary Adenocarcinoma of the Endometrium Coincide with Tuberculous Lymphadenitis
}

\author{
Endometrium Adenokarsinomu ile Birlikte Abdominal Lenf Bezlerinde Tüberküloz Lenfadenit
}

\author{
Ayșe Önal Aral', Reyhan Öçalan², Heyecan Ökten³, Gökhan Tulunay²

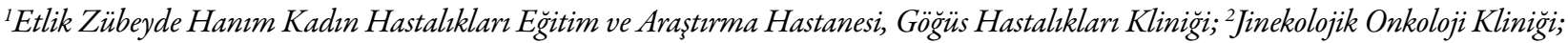 \\ ${ }^{3}$ Patoloji Laboratuar, Ankara, Türkiye
}

\begin{abstract}
Endometrial adenocarcinoma is one of the most prevalent carcinoma in women. Tuberculous lymphadenitis is one of the most common presentation of extrapulmonary tuberculosis, involving usually lymph nodes in the region of neck and head, rarely in other regions of the body. In the literature, the coexistence of endometrial adenocarcinoma and tuberculosis have been reported to be scarce. But, we have not found any case who had both endometrial adenocarcinoma and isolated lymph node tuberculosis in abdominal cavity in the literature.

A 49-year-old woman underwent on the surgical operation due to the mass spotted in her uterine cavity. Pathological diagnosis of the mass was revealed to be grade 1 endometrial adenocarcinoma. In addition, a lot of enlarged and softened lymph nodes were observed in abdomen during surgical operation, being disclosed granulomatous inflammation in all and caseating necrosis in addition to multinucleate giant cells of Langhans in some through histopathological examination. Any finding referring to malignancy or tuberculous infection was not found as a result of pathological examination of tissue samples obtained from ovaries, myometrium, cervix, fallopian tubes and peritoneum. So, the case was diagnosed to be primary endometrial adenocarcinoma coincide with isolated tuberculous lymphadenitis. Antituberculous treatment was started to be followed for both diseases. The patient has completed a six month quadruple antituberculous treatment with no adverse effect.
\end{abstract}

Key words: endometrial adenocarcinoma; tuberculous lymphadenitis; tuberculosis

\section{ÖZET}

Endometrium adenokarsinomu, kadınlarda en sık görülen kanser türlerinden biridir. Tüberküloz lenfadenit, ekstrapulmoner tüberküloz olgularının en sık rastlanan formlarından biridir; en sık baș ve boyun bölgesindeki, seyrek olarak da diğer vücut bölgelerindeki lenf bezlerinde tespit edilir. Literatürde endometrium karsinomunun genital tüberküloz ile eșzamanlı saptandığı az sayıda vaka bildirilmiștir. Ancak, endometrium adenokarsinomu ve izole abdominal lenf bezi tüberkülozunun birlikte saptandığı herhangi bir vakaya literatürde rastlanmadı.

Ayse Önal Aral, Yenimahalle, 06010 Ankara - Türkiye, Tel. 05357632638 Email.aonal2@yahoo.com

Geliş Taribi: 12.11.2015 • Kabul Taribi: 12.05.2017
Kırk dokuz yașında bayan hasta uterus boșluğunda kitle saptanması nedeniyle operasyona alındı. Endometriumdaki kitlenin patolojik tetkiki sonucu, grade 1 endometrium adenokarsinomu tanısı konuldu. Operasyon sırasında batında izlenen çok sayıda, büyümüș, yumușak kıvamlı lenf bezlerinin hepsinde patolojik olarak granülomatöz lenfadenit, bazılarında santral kazefikasyon ve Langhans tipi dev hücreler izlendiği rapor edildi. Uterus, salpenksler, overler, omentum ve serviksten alınan doku materyallerinin patolojik değerlendirmesinde malignite veya tüberküloz infeksiyonunu ișaret edebilecek herhangibir bulguya rastlanmadı. Vaka, eș zamanlı izole abdominal lenf bezi Tüberkülozu ve primer endometrium adenokarsinomu olarak değerlendirildi; antitüberküloz tedaviye bașlanarak her iki hastalık için takibe alındı ve altı aylık tedaviyi herhangi bir yan etki görülmeksizin tamamladı.

Anahtar kelimeler: endometrium adenokarsinomu; tüberküloz lenfadenit; tüberküloz

\section{Introduction}

Tuberculosis (TB) is an infectious disease, which is able to involve almost every organ system in the body. While pulmonary tuberculosis is the most common presentation of the diseases, the prevalence of extrapulmonary tuberculosis (EPTB) has increased in our era because of the cases infected with human immunodeficiency virus (HIV) ${ }^{1}$. EPTB develops due to reactivation of dormant Mycobacterium tuberculosis bacilli which spread other organs in the body via lymphohematogen system during primary tuberculous infection, as a result of decreased immunity or increased sensitivity of the body against the microorganism at some point of the life. TB of lymph nodes is the most common form of EPTB following pleural tuberculosis. Lymph nodes in the region of the neck and the head are frequently involved in line with lymphatic drainage anatomically.

TB of intraabdominal lymph nodes is not common in the literature. So, our case was interesting in terms of 
involvement of intraabdominal lymph nodes by TB separately alongside endometrial adenocarcinoma (EA).

\section{Case Report}

A 49 year-old woman was admitted to our hospital with a mass of $46 \times 48 \times 52 \mathrm{~mm}$ in size in uterine cavity in addition to a few myomatous lesions, being operated on. Endometrial mass was revealed to be grade
1 EA by pathological examination. Moreover, many enlarged and softened lymph nodes with the largest one of $4 \times 3 \mathrm{~cm}$ in size in the upper and lower paraaortic region were seen during operation to be determined granulomatous inflammation in frozen section (Figure 1). Total abdominal histerectomy and bilateral salpingoophorectomy was performed on the patient later to be consulted with clinic of chest diseases so as to be investigated for granulomatous lymphadenitis. She presented with complaints of weight loss

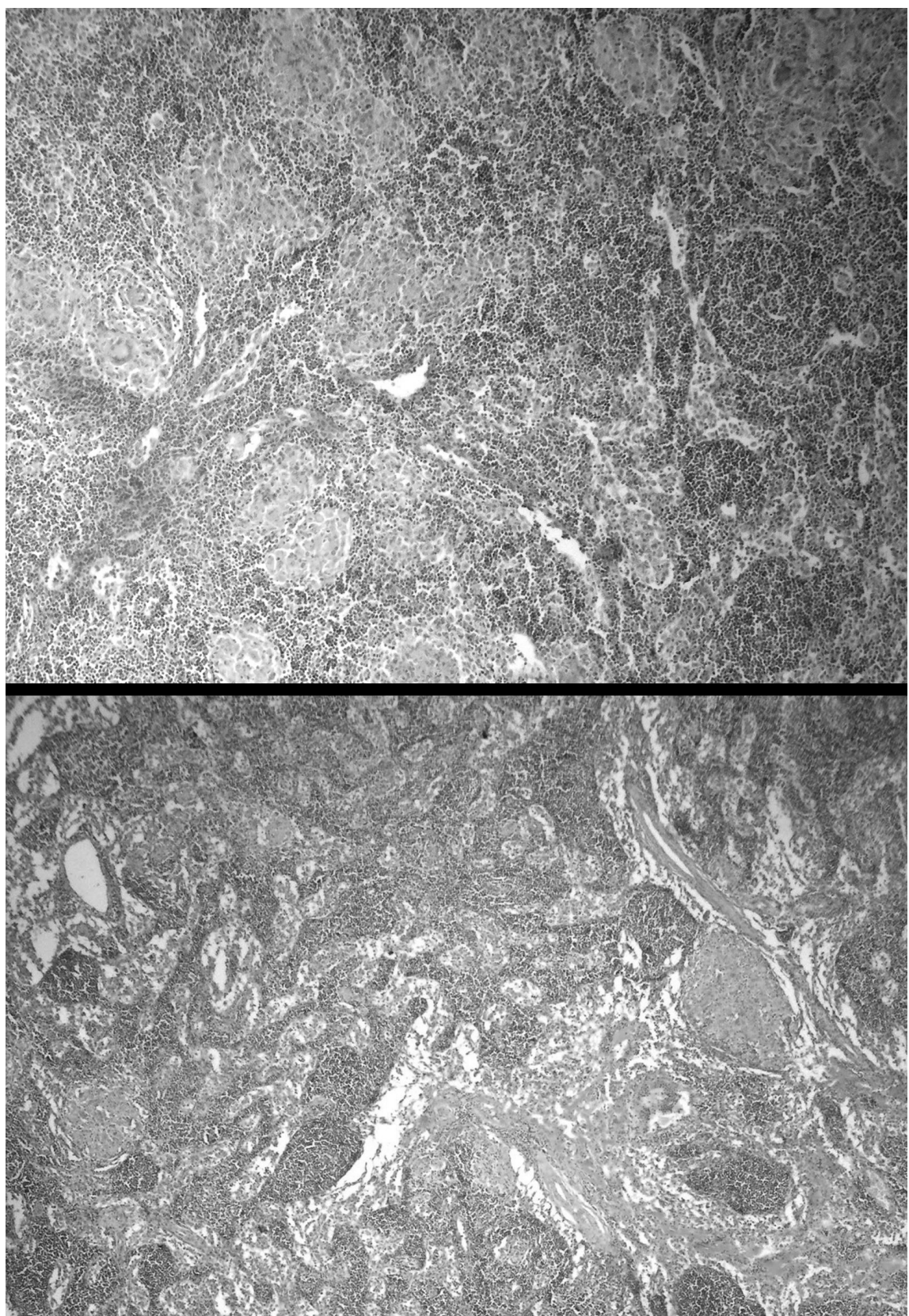

Figure 1. Granulomatous inflammation in lymph nodes. 
and loss of appetite for the last one month. She had diabetes for sixteen years to receive treatment of oral antidiabetic. Her past history also disclosed that one neighbor of her had had pulmonary tuberculosis fifteen years before. The physical examination, chest $\mathrm{x}$-ray, and chest computerized tomography revealed no abnormalities. She had a BCG scar and proved a response of $2 \mathrm{~mm}$ in size to purified protein derivative (PPD) test. The patient presented free abdominal fluid of chylous character fifteen days after surgery. Examination of fluid was negative for acid resistant bacteria (ARB) and reproduction in selective media was not been observed for ARB. Laboratory tests revealed level of adenosine deaminase (ADA) in parasentes fluid to be 10 (0-40 U/L). Hb was 10 (11-18 $\mathrm{gr} / \mathrm{dL}$ ), and carcinogenic antigen 125 (CA 125) 44.3 $(0-35 \mathrm{IU} / \mathrm{ml})$ in blood sample as abnormal findings. Samples obtained in the course of surgical operation and being detected granulomatous inflammation were again examined pathologically and microbiologically using PAS (=periodic acid-Schiff), ARB and giemsa stain to be revealed granulomatous inflammation in all lymph nodes samples as well as giant cells for Langhans and central caseating in some and no microorganism. The case was determined to be EA stage 1A (T1a, N0, M0) to be put follow up and quadruple antituberculous therapy including isoniazid, rifampin, ethambutol, pyrazinamide was started. The level of CA 125 in the blood had been normal range since third month of antituberculous therapy. The patient has completed a six month antituberculous therapy with no complication to be put follow up for both TB and EA.

\section{Discussion}

Tuberculous infection of lymph nodes in pelvis and abdomen usually accompanies tuberculous infection of peritoneum, intestin, and genital tract. Our case was not revealed any finding related $\mathrm{TB}$ as a result of pathological examination of samples including omentum, fallopian tubes, ovaries, myometrium and servix while epiteloid cells, giant cells for Langhans and central caseating, which is patognomonic for TB, were revealed in the lymph nodes in pelvis and abdomen. Malignancy was not detected in the lymph nodes. The cases with endometrial adenocarcinoma are rarely seen to be coincide with tuberculous infection of genital tract in the literature. In one case previously declared it was diagnosed that EA coincided with endometrial tuberculosis without lymph nodes involvement ${ }^{2}$ while in another case, EA coincided with endometrial tuberculosis as well as tuberculous infection of other genital organs involving cervix, fallopian tubes and regional lymph nodes ${ }^{3}$. Our case presented with isolated lymph node tuberculosis in the region of pelvis and abdomen and EA coincidently as separate diseases.

Our case initially presented high level of CA 125 in blood with declining normal range of level after a three-month of antituberculous treatment. Although CA 125 usually increases in ovarian carcinoma, it was reported that it could increase in pelvic and peritoneal tuberculosis and decrease normal range after anti tuberculous therapy so it can be used for follow up those patients ${ }^{4,5}$. What is more, CA 125 can increase in EA in line with the stage of the disease ${ }^{6}$ and in benign lesions of genital organs like myoma ${ }^{7}$. Our case was revealed both $\mathrm{EA}$ and a few of uterin myomatous lesions in addition to TB of lymph nodes.

The response of the PPD test of our case was negative. Positive response to PPD test in EPTB has been reported to be vary in the range of $20-80 \%$ in the studies $^{8}$. People with weak immunity or suppressed immunity due to HIV or malignancy can show no response to PPD test ${ }^{9}$. Diabetes and malignancy must have impaired immunity of our case.

Tuberculous is one of the most prevalent ones among infectious diseases diagnosed in patients with diabetes. This is attributed to the weak immunity of this group of patients. According to a study published recently, diabetes was common in patients with $\mathrm{EPTB}^{10}$.

As a result, it should be kept in the mind that enlarged lymph nodes in abdomen and pelvic region can result from other diseases like TB apart from malignancy.

\section{References}

1. Mehta JB, Dutt A, Harvill L, Mathews KM. Epidemiology of extrapulmonary tuberculosis. A comparative analysis with preAIDS era. Chest 1991;99(5):1134-8.

2. Saygili U, Guclu S, Altunyurt S, Koyuncuoglu M, Onvural A. Primary endometrioid adenocarcinoma with coexisting endometrial tuberculosis. A case report. J Reprod Med 2002;47(4):322-4.

3. Castelo-Branco C, Mallofre C, Torné A, Gratacós E, Iglesias Guiu X. Primary adenocarcinoma of the endometrium associated with genital tuberculosis. A case report J Reprod Med 1995;40(9):673-5.

4. Kiu MC, Hsueh S, Ng SH, Chen JS. Elevated serum CA-125 in tuberculous peritonitis: report of a case J Formos Med Assoc 1994;93(9):816-8. 
5. Mas MR, Cömert B, Sağlamkaya U, Yamanel L, Kuzhan O, Ateşkan U, et al. CA-125; a new marker for diagnosis and follow-up of patients with tuberculous peritonitis. Dig Liver Dis 2000;32(7):595-7.

6. Nikolaou M, Kourea HP, Tzelepi V, Adonakis G, Scopa CD, Tsapanos V, et al. The prognostic role of preoperative serum CA 125 levels in patients with endometrial carcinoma. J BUON 2014;19(1):198-202.

7. Ghaemmaghami F, Karimi Zarchi M, Hamedi B. . High levels of CA125(over 1, $000 \mathrm{IU} / \mathrm{ml}$ ) in patients with gynecologic disease and no malignant conditions: three cases and literature review. Arch Gynecol Obstet 2007;276(5):559-61.
8. Özsoy-Hitit G, Göktaş P, Erdem İ, Özyürek SÇ, Yüksel S. Erişkinde67 akciğerdışı tüberküloz olgusunun değerlendirilmesi, İnfeksiyon Derg 2005;19(4):407-13.

9. Türkiye'de Tüberkülozun kontrolü için başvuru kitabı, TC Sağlık Bakanlığı Verem Savaş Daire Başkanlığı, Ankara 2003:55-7.

10. Magee MJ, Foote M, Ray SM, Gandhi NR, Kempker RR. Diabetes mellitus and extrapulmonary tuberculosis: site distribution and risk of mortality. Epidemiol Infect 2016;1:1-8. 